\title{
Slump folds within mid-Miocene crevasse-splay deposits: a unique example from the Tomisławice lignite opencast mine in central Poland
}

\author{
Marek WIDERA ${ }^{1, *}$ \\ 1 Institute of Geology, Adam Mickiewicz University, Krygowskiego 12, 61-680 Poznań, Poland
}

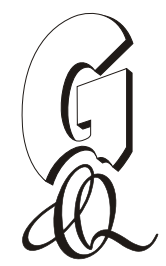

\begin{abstract}
Widera, M., 2020. Slump folds within mid-Miocene crevasse-splay deposits: a unique example from the Tomisławice lignite opencast mine in central Poland. Geological Quarterly, 64 (3): 711-722, doi: 10.7306/gq.1545

Non-tectonic, soft-sediment deformation structures occur in mid-Miocene crevasse-splay deposits exposed in the Tomisławice lignite opencast mine in central Poland. The crevasse-splay cross-stratified siliciclastic deposits are underlain by continuously folded and relatively thick lignite beds, and overlain by a thin undisturbed layer of lignite. Only the middle part of the crevasse-splay succession is deformed plastically in the form of folds, while the lower and uppermost beds are undeformed. Most of the intraformational deformation structures are recumbent folds, while only a few can be classified as upright folds in the initial stage of their evolution. The origin of these folds is associated here with a penecontemporaneous slumping process caused by liquefaction of sandy-muddy sediments. The slumping was triggered by an increase in the inclination of heterolithic layers caused by the compactional subsidence of an organic-rich substrate - peat. This type of subsidence occurred following a sudden siliciclastic load on top of the underlying and poorly-compacted peat/lignite seam. The initiation and development of the slump folds can be explained by differentiated loading, compaction and liquefaction processes, and the introduction of a tectonic agent is unnecessary.
\end{abstract}

Key words: crevasse-splay facies, lignite lithotypes, slump folds, soft-sediment deformation, Konin Basin, Neogene.

\section{INTRODUCTION}

Slumping can occur in unconsolidated sediments of various lithology, origin and age. The slumped beds can reach thicknesses ranging from a few centimetres to tens of metres, while individual folds may be up to several metres thick, a few decimetres on average (Roberts, 1972; Li et al., 2019 and references therein). In general, these slump structures belong to a larger group of soft-sediment deformation structures (SSDS) as summarized by Moretti et al. (2016) and Shanmugam (2017).

The slump folds investigated come from the Tomisławice opencast mine in central Poland, where lignite of mid-Miocene age is currently mined (Fig. 1). Geometrically similar folds are widely described among sedimentary rocks ranging in age from Precambrian to modern (e.g., Leedal and Walker, 1950; Strachan and Alsop, 2006; Dasgupta, 2008; Strachan, 2008; van Loon, 2009; Alsop and Marco, 2011; Kundu et al., 2011; Ta gın et al., 2011; Waldron and Gagnon, 2011; Moretti and Van Loon, 2014; Whitmore et al., 2015; Alsop et al., 2016; Olabode, 2016; Byun et al., 2019 and references therein).

\footnotetext{
*E-mail: widera@amu.edu.pl
}

Received: March 20, 2020; accepted: May 26, 2020; first published online: 24 July, 2020
Slump folds have also been generated experimentally (McKee et al., 1962; Owen, 1996; Moretti et al., 1999; Dasgupta, 2008).

Liquefaction and/or fluidisation of sediments that have not undergone complete lithification are necessary for the formation of these slump folds (Allen, 1982). Yet, the origin and trigger mechanisms of slump structures remain debatable. Most researchers consider that the sediment liquefaction/fluidisation process can only be triggered by seismic activity, while others have a different view (e.g., Shanmugam, 2017). This important issue, related to the tectonic or nontectonic origin of slump folds, has been summarized and discussed in detail (e.g., Allen and Banks, 1972; Røe and Hermansen, 2006; Mazumder and Altermann, 2007; Whitmore et al., 2015).

Many aspects of soft-sediment deformation, both plastic and brittle, of crevasse-splay and accompanying siliciclastic strata from lignite opencast mines in the Konin Basin have been described and discussed (Widera, 2017; Chomiak et al., 2019a, b; van Loon, 2019). However, according to the author's knowledge, slumped crevasse-splay deposits within lignite seams have not yet been studied. Therefore, this case study (1) describes and interprets the siliciclastic facies of the crevasse splay and accompanying lignite lithotypes; (2) identifies, characterises and explains the origin of the slump folds occurring within the crevasse-splay body; (3) discusses other possible processes for creating the slump folds and their trigger mechanisms; and (4) proposes an idealized conceptual model for the formation of these slump folds. 


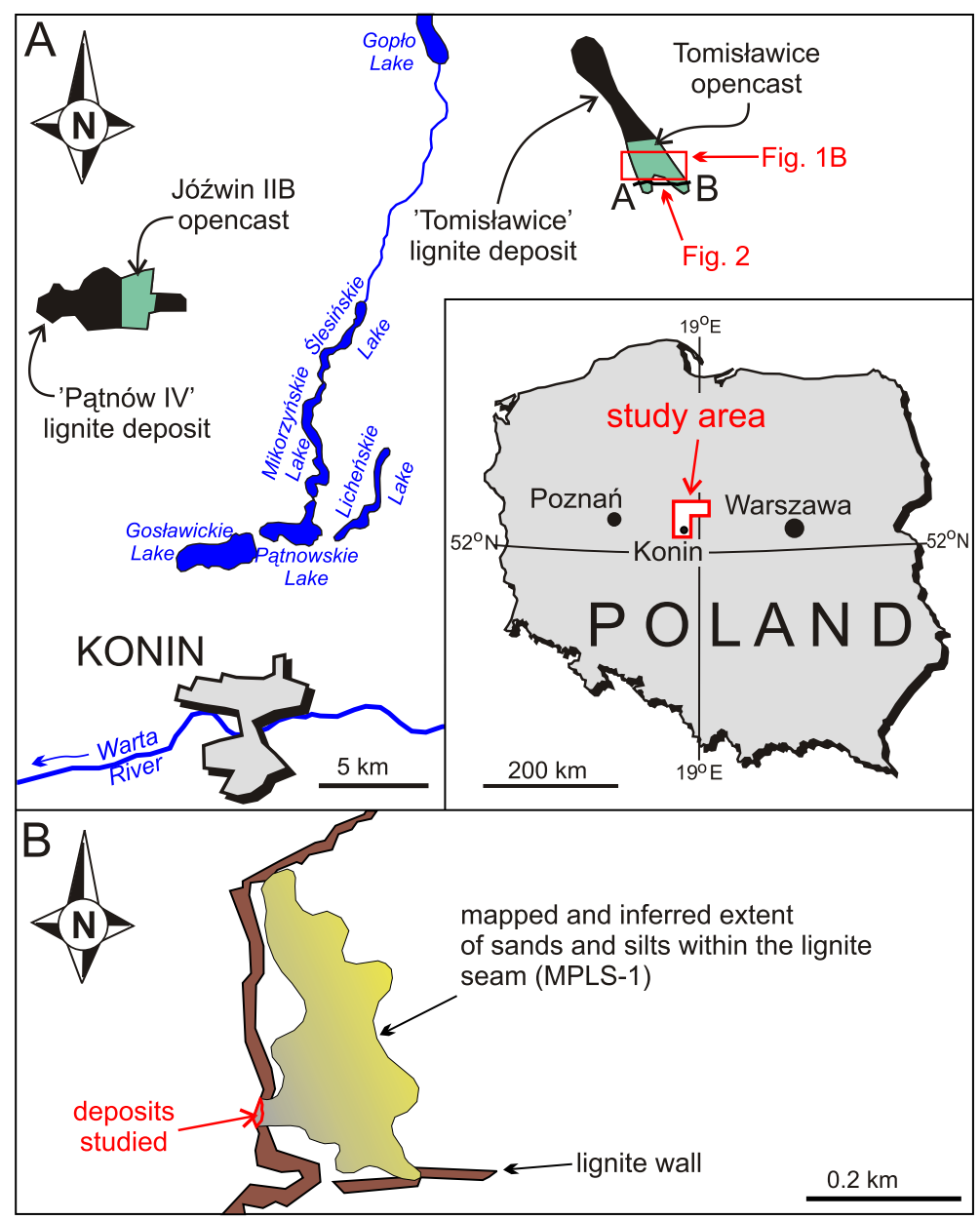

Fig. 1. Location map

A - general location of the study area in the Konin vicinity; B - detailed location of the deposits studied (52 $\left.45^{\prime} 39^{\prime \prime} \mathrm{N}, 18^{\circ} 51^{\prime} 80^{\prime \prime} \mathrm{E}\right)$ in the Tomisławice lignite opencast mine
Tomisławice territory is $6.9 \mathrm{~m}$ (Fig. 2). It was deposited during the final phase of the mid-Miocene Climatic Optimum (Zachos et al., 2001), making its age as the middle part of the Middle Miocene (Kasiński and Słodkowska, 2016; Bechtel et al. 2019, 2020; Worobiec et al., 2020).

Numerous sandy-muddy lenses occur within the MPLS-1 in the Konin Basin, including the Tomisławice opencast mine (Fig. 2). These are interpreted as typical crevasse splays that deposited sediment in the fluvial plain area of a mid-Miocene fluvial system. Thus, the MPLS-1 evolved from low-lying mires, which can be referred to as backswamps (Widera, 2016a; Widera et al., 2017a Chomiak et al., 2019a; Chomiak, 2020). As a result, the MPLS-1 contains a relatively high ash yield $\left(10<A^{d}<20\right.$ wt. $\left.\%\right)$, mostly in the form of detrital quartz grains, and a low average sulphur content (<1.2 wt.\%; Kwiecińska and Wagner, 1997; Bechte et al., 2019, 2020). The MPLS-1 is also characterized by a low average reflectance coefficient ( $R r$ $<0.3 \%)$ and carbon content $\left(60<C^{d a f}<70 \%\right)$. Therefore, the lignite in this seam is classified as humic and low-rank $\mathrm{B}$, that is, ortho-lignite (Kwiecińska and Wagner, 2001; Bielowicz, 2012).

The Wielkopolska Member of upper mid-Miocene to lowermost Pliocene age represents the end of Neogene sedimentation in the area studied (Piwocki and Ziembińska-Tworzydło, 1997). It contains overbank muds with palaeosol horizons (>95 vol.\%), as well as channel-fill sands and muds ( $<5$ vol.\%). Its origin has been recently interpreted as a fluvial system (e.g., Maciaszek et al., 2019 2020; Widera et al., 2017b, 2019; Zieliński and Widera, 2020). Glaciogenic Quaternary deposits (tills, gravels, sands and muds) rest on top of the Neogene formations (Fig. 2).

\section{MATERIALS AND METHODS}

Fieldwork was carried out in the Tomisławice lignite opencast mine (Fig. 1A) and included sedimentological and structural observations of the sandy-muddy lithosome belonging to the MPLS-1 and visible on the western wall of the opencast (Figs. 1B and 2). Fifteen samples were collected for preliminary grain-size analysis, and the underlying and overlying lignite beds were mapped to determine the presence or absence of deformation within them. Additionally, data from 11 boreholes were used to prepare the representative geological cross-section (Fig. 2). All of this information, including mining maps, was obtained from the geological archive of the Konin Lignite Mine.

The standard classification of siliciclastic rocks was used to characterize the sampled sediments that were texturally divided into sands, sandy muds and muddy sands. To simplify their description, a modified version of the original facies codification of Miall (1977) was used. When the content of clayey-silty grains exceeded 50 wt.\% and the silt content was within the range 33-66 wt.\%, the term "mud", according to Lundegard and Samuels (1980), was applied. Hence, in contrast to the original Miall codification, the letter "M" was used for mud - as defined above (cf. Fig. 3 and Table 1).

For textures of lignite lithotypes, the proportions between the xylitic (woody) fragments and fine detrital matrix were taken and occurring within the Grey Clays Member. The MPLS-1 is up to several metres thick, and its average thickness in the 


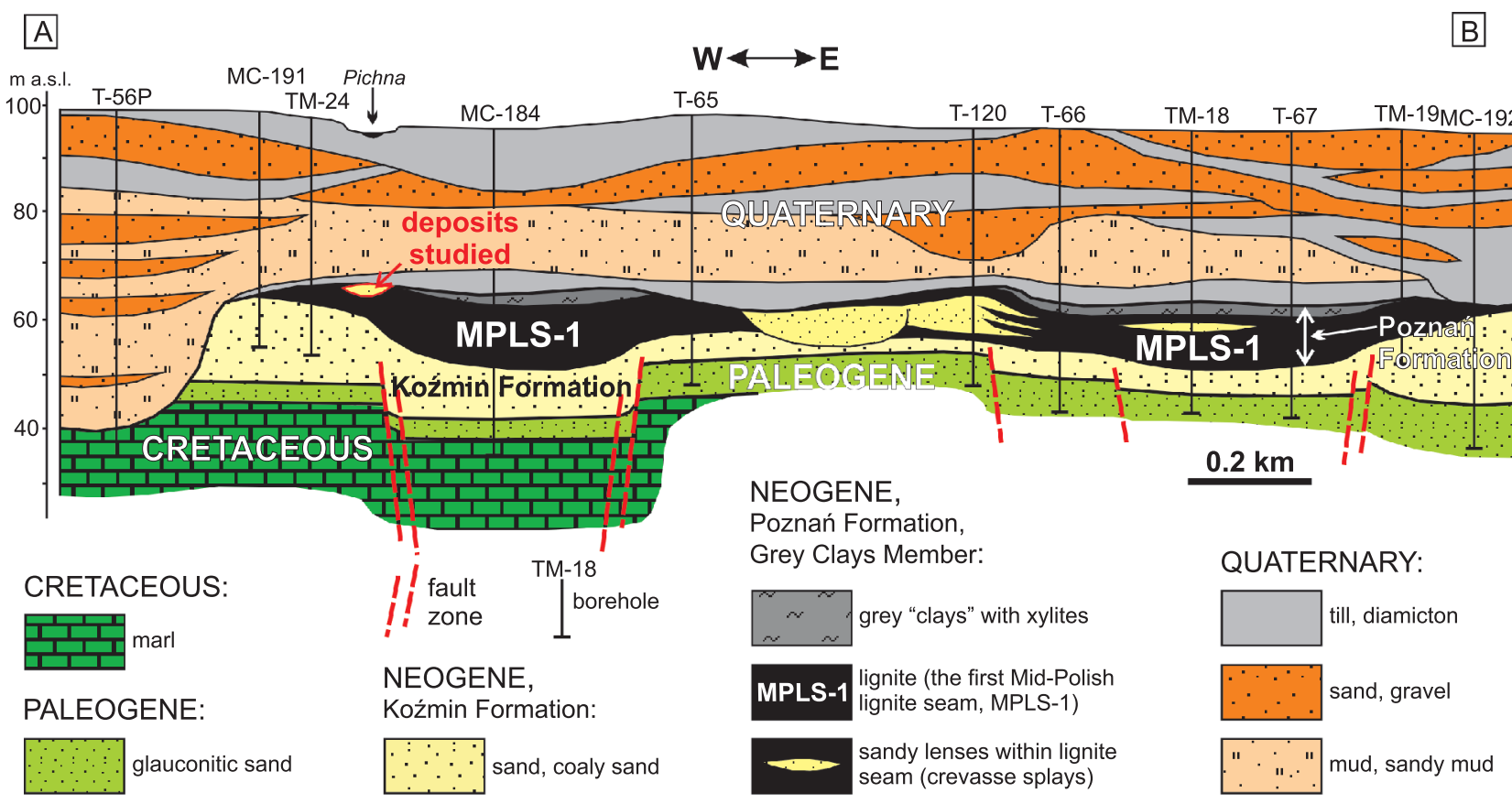

Fig. 2. Geological cross-section through the "Tomisławice" lignite deposit (modified from Widera et al., 2017a)

Note the approximate position of the studied deposits within the first Mid-Miocene lignite seam (MPLS-1); for location of the cross-section line see Figure $1 \mathrm{~A}$

into consideration (Wolf, 1988; Kwiecińska and Wagner, 1997; Kolcon and Sachsenhofer, 1999). However, their structures were similar to those commonly found in the clastic deposits, that is, massive and deformed (folded). Finally, the overall relationship between the peat-forming mire and the resulting lignite lithotype is based on the original contribution of Teichmüller (1958), which was subsequently supplemented by Teichmüller (1989), Markič and Sachsenhofer (1997), Ticleanu et al. (1999), and Widera (2012, 2016b).

All planar structures, such as stratification and fold axial planes, were measured with a geological compass according to generally accepted convention (Ramsay and Huber, 1987; Dadlez and Jaroszewski, 1994). Twenty-four measurements were carried out in the field covering palaeodirections of water flow and slump transport (Fig. 3). Furthermore, to classify the folds, the dip of the axial plane was considered. According to this classification, the following types of folds were distinguished: upright, inclined, recumbent and reclined (Rickard, 1971; Waldron and Gagnon, 2011).

\section{FACIES, LITHOTYPES AND DEPOSITIONAL PALAEOENVIRONMENTS - RESULTS AND INTERPRETATION}

\section{SILICICLASTIC FACIES}

The siliciclastic body is located close to the seam's roof, and it is up to $3.6-4.0 \mathrm{~m}$ thick and $65 \mathrm{~m}$ long in a north-south direction. Its top is almost flat, while the base is uneven and concave upwards (Fig. 4). Among these siliciclastic deposits, several sandy-muddy facies are described and interpreted in the text: Figure 3 and Table 1.

Description. The siliciclastic facies consist of alternating sandy and sandy-muddy or muddy-sandy layers. Their individual thickness ranges from $<1 \mathrm{~mm}$ to $>10 \mathrm{~cm}$ (Figs. 3-7). The facies classification depends on the weight proportions of sand, silt and clay. Almost all these facies were originally trough cross-stratified with lamination dipping at an average azimuth of $100^{\circ}$ (Fig. 3).

Currently, the primary stratification is preserved only in the lower and upper parts of the siliciclastic lithosome (Figs. 4-6), where the layers are inclined towards the E and ESE, respectively (Fig. 3). In the middle portion, the stratification is strongly folded (Figs. 3, 4 and 7). An exception is one bed, which is plane-parallel (horizontally) laminated in the middle part of the succession (Figs. 3 and 7 A).

Interpretation. The siliciclastic facies should be attributed to a crevasse splay formed on the surface of a mid-Miocene mire. Simply put, all of the facies represent a crevasse-splay facies association (e.g., Aslan and Autin, 1999; Bristow et al., 1999; Zieliński, 2014; Kędzior, 2016; Burns et al., 2017). Taking into account the geometry (channel-like) and location (above the thick lignite bed) of this association, the facies can be interpreted as the most proximal part of the splay. This statement is supported by the base being evidently erosional (Fig. 4 and Table 1). The channel-like geometry with low aspect ratio (width/thickness 16) and dominance of large-scale cross-bedding represent a crevasse channel, which is typical of a type-1 crevasse splay (Farrell, 2001).

Large-scale trough cross-stratification of both sand (St), sandy mud (MSt) and muddy sand (SMt) are commonly considered as progressive filling of troughs in front of moving three-dimensional dunes produced in the upper part of the lower flow 


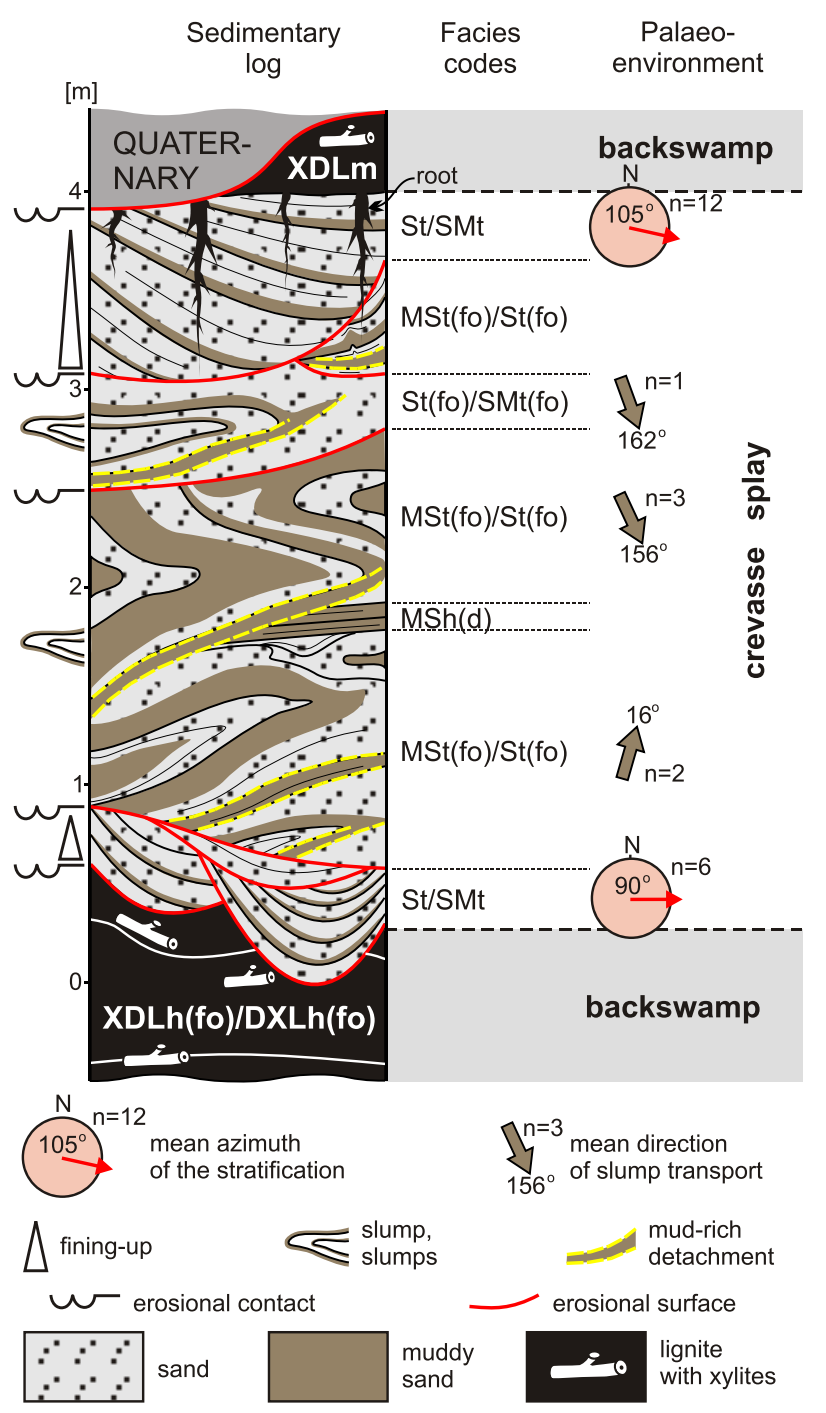

Fig. 3. Generalized sedimentary log of the crevasse-splay deposits and accompanying lignites

For siliciclastic facies and lignite lithotype codes, description and interpretation see the text and Table 1

regime (Allen, 1965; Collinson and Thompson, 1982; Bridge, 2003; Zieliński, 2014). However, as inferred from alternating sandy-muddy bedding, current flow was variable (Miall, 1977; Allen, 1982, 1984). Conversely, horizontally laminated sandy mud (MSh) is linked with tractional transport via unconfined sheet flow under upper-flow regime conditions (Allen, 1984; Zieliński, 2014).

The deposition of the facies interpreted (St, MSt, SMt) took place on an unstable substrate, where the peat was poorly compacted and water-saturated. Generally, the palaeotransport direction was in the range from east to south-east (Fig. 3), which is of fundamental importance in clarifying the origin of the deformation structures. Most of the siliciclastic facies were deformed, namely folded, penecontemporaneously (during or shortly after deposition; cf. Fig. 3 and Table 1), and hence, the major subject of the present study.

\section{LIGNITE LITHOTYPES}

In this paper, only those lignite lithotypes that directly accompany the crevasse-splay deposits examined are characterized. Deformation structures of the lignite beds are particularly important in the context of this study, in which the textural and structural features of each lithotype are described, followed by their palaeoenvironmental interpretation.

Description. Three texturally similar lignite lithotypes were distinguished in the field: xylodetritic lignite with a massive structure - XDLm, xylodetritic lignite with a horizontal and folded stratification - XDLh(fo), as well as detroxylitic lignite with horizontal and folded stratification - DXLh(fo) (cf. Fig. 3 and Table 1). They all are predominantly composed of a mixture of xylitic $(>1 \mathrm{~cm})$ and detrital $(<1 \mathrm{~cm})$ constituents totalling $>90$ vol.\%. The difference in texture between XDL and DXL is paradoxically apparent in that DXL contains more xylitic than detrital elements, and for the XDL it is the opposite.

The upper lignite layer (upper bench of lignite seam) is only up to $0.6 \mathrm{~m}$ thick and is made up of the single lithotype XDLm, which is characterized by non-disturbed structure. By contrast, the lower lignite bed (main lower bench of lignite seam) is relatively thick, reaching $10 \mathrm{~m}$. In the present study, two facts are most important: the roof of this lignite bench is erosional; and its uppermost parts are strongly disturbed in the form of folds with an amplitude of 1-2 m (Fig. 4).

Interpretation. All lignite lithotypes described above are characteristic of the mid-Miocene mires that existed in central Poland. These developed in close proximity to the river channels or between them, and hence can be interpreted as backswamps (Davies-Vollum and Kraus, 2001). This is consistent with the presence of crevasse-splay bodies (one of them being the subject of this study) within the MPLS-1 in the Konin Basin (Widera, 2016a, 2017; Chomiak et al., 2019a).

The xylodetritic and detroxylitic lignite lithotypes (XDL and DXL) interpreted were formed in transitional palaeoenvironmental conditions that were neither too dry nor too wet. Most likely, DXL represents a wet forest swamp, while XDL is attributed to a bush moor (Markič and Sachsenhofer, 1997; Kolcon and Sachsenhofer, 1999; Ticleanu et al., 1999). Taking into account the dominant plant composition, these palaeomires are named the Taxodium-Nyssa and Myricaceae-Cyrillaceae swamps, respectively (Teichmüller, 1958, 1989; Table 1).

The most important structural feature here is the folded structure of the lower bench of the MPLS-1 (Figs. 3 and 4). Even if the lignite stratification is barely visible, most horizontal layers were likely folded during and after their deposition. This was clearly due to the load of the crevasse-splay sediments that were deposited on the top of a still poorly-compacted and water-saturated peat/lignite seam. As a result, the lignite layers are concave upwards, where the thickness of the crevasse deposits is greater. The load on the underlying peat was uneven, which resulted in pushing up both lignite and clastic layers by $>1 \mathrm{~m}$ in the axial zone, as well as on the northern flank of the crevasse-splay body (Fig. 4).

\section{DEFORMATION STRUCTURES WITHIN THE CREVASSE-SPLAY DEPOSITS}

The majority of deformation structures identified in the field were recumbently-folded cross-sets. Other types of folds occurred only sporadically; for example, upright folds. They are characterized below in order of abundance. 
Table 1

Characteristics of the crevasse-splay facies and accompanying lignite lithotypes genetically related to the slumped cross-beds in the Tomisławice lignite opencast mine in central Poland

\begin{tabular}{|c|c|c|c|c|}
\hline Environment & Code & Facies name & Facies description & Depositional setting \\
\hline \multirow{4}{*}{$\begin{array}{l}\text { Crevasse splay } \\
\text { (proximal zone) }\end{array}$} & St/SMt & $\begin{array}{l}\text { Sand and muddy } \\
\text { sand with a trough } \\
\text { cross-stratification }\end{array}$ & $\begin{array}{l}\text { Co-set up to } 0.8-0.9 \mathrm{~m} \text { thick; individual } \\
\text { sets up to 0.3-0.8 m thick; concave-up, } \\
\text { erosional bases; present in the } \\
\text { lower- and uppermost parts of the } \\
\text { crevasse-splay succession }\end{array}$ & $\begin{array}{c}\text { Deposition from traction as 3D dunes in } \\
\text { upper part of lower flow regime (Allen, } \\
\text { 1965; Collinson and Thompson, 1982; } \\
\text { Bridge, 2003; Zieliński, 2014) }\end{array}$ \\
\hline & $\operatorname{MSh}(d)$ & $\begin{array}{l}\text { Deformed sandy } \\
\text { mud with a } \\
\text { plane-parallel } \\
\text { (originally horizon- } \\
\text { tal; slightly inclined) } \\
\text { stratification }\end{array}$ & $\begin{array}{c}\text { Up to } 0.1-0.2 \mathrm{~m} \text { thick; dominant mud } \\
\text { content with parallel lamination; flat ero- } \\
\text { sional base; located only occasionally } \\
\text { between strongly disturbed deposits in } \\
\text { the middle part of the crevasse-splay } \\
\text { succession }\end{array}$ & $\begin{array}{l}\text { Synsedimentary inclined; originally, } \\
\text { tractional deposition by plane-bed trans- } \\
\text { port - sheet flow; supercritical flow; } \\
\text { upper-stage plane conditions (Miall, } \\
\text { 1977; Allen, 1982, 1984; Zieliński, 2014) }\end{array}$ \\
\hline & $\begin{array}{l}\text { MSt(fo)/ } \\
\text { St(fo) }\end{array}$ & $\begin{array}{l}\text { Folded sandy mud } \\
\text { and mud with } \\
\text { a trough cross-strat- } \\
\text { ification }\end{array}$ & $\begin{array}{l}\text { Co-set up to } 1.6-1.8 \mathrm{~m} \text { thick; individual } \\
\text { sets up to } 0.2-0.6 \mathrm{~m} \text { thick; dominant } \\
\text { sandy-muddy beds; bases parallel to } \\
\text { the erosional surfaces; this facies cover } \\
\text { the largest, middle part of the } \\
\text { crevasse-splay succession }\end{array}$ & $\begin{array}{c}\text { Synsedimentary folded as slumps; origi- } \\
\text { nally, tractional deposition as 3D dunes } \\
\text { in upper part of lower flow regime (Allen, } \\
\text { 1965; Collinson and Thompson, 1982; } \\
\text { Bridge, 2003; Zieliński, 2014) }\end{array}$ \\
\hline & $\begin{array}{l}\text { St(fo)/ } \\
\text { SMt(fo) }\end{array}$ & $\begin{array}{l}\text { Folded sand and } \\
\text { muddy sand with } \\
\text { a trough cross- } \\
\text { stratification }\end{array}$ & $\begin{array}{l}\text { Co-set and individual sets up to } 0.5 \mathrm{~m} \\
\text { thick; dominant sandy layers; parallel to } \\
\text { the erosional surfaces; this facies is pres- } \\
\text { ent only in upper, but not the uppermost, } \\
\text { part of the crevasse-splay succession }\end{array}$ & $\begin{array}{l}\text { Depositional interpretation } \\
\text { and references as above }\end{array}$ \\
\hline Environment & Code & Lithotype name & Lithotype description & Depositional setting \\
\hline \multirow[b]{2}{*}{$\begin{array}{c}\text { Mire } \\
\text { (low-lying mire) }\end{array}$} & XDLm & $\begin{array}{l}\text { Xylodetritic lignite } \\
\text { with a massive } \\
\text { structure }\end{array}$ & $\begin{array}{l}\text { Up to } 0.6 \mathrm{~m} \text { thick; >90 vol.\% of plant de- } \\
\text { tritus and xylites, although plant detritus } \\
\text { prevails over xylites; massive structure; } \\
\text { sedimentary floor; roof cut by mining ac- } \\
\text { tivities; upper bench of lignite seam } \\
\text { overlying the crevasse-splay deposits }\end{array}$ & $\begin{array}{l}\text { Mire (backswamp) with a bush moor; } \\
\text { Myricaceae-Cyrillaceae swamp } \\
\text { (Teichmüller, 1958, 1989; Markič and } \\
\text { Sachsenhofer, 1997; Kolcon and } \\
\text { Sachsenhofer, 1999; Ticleanu et al., } \\
\text { 1999; Widera, 2012, 2016b) }\end{array}$ \\
\hline & $\begin{array}{l}\text { XDLh(fo)/ } \\
\text { DXLh(fo) }\end{array}$ & $\begin{array}{l}\text { Xylodetritic and } \\
\text { detroxylitic lignite } \\
\text { with a horizontal } \\
\text { and folded } \\
\text { stratification }\end{array}$ & $\begin{array}{c}6-10 \mathrm{~m} \text { thick; >90 vol.\% of plant detritus } \\
\text { and xylites in varying proportions; in the } \\
\text { upper part visible folding; in the lower } \\
\text { part hardly visible original, horizontal } \\
\text { stratification; sedimentary floor; evi- } \\
\text { dently erosional roof; lower bench of lig- } \\
\text { nite seam underlying the crevasse-splay } \\
\text { deposits }\end{array}$ & $\begin{array}{c}\text { Postdepositionally folded under uneven } \\
\text { load; originally, mire (backswamp) with a } \\
\text { bush moor or wet forest swamp; } \\
\text { Myricaceae-Cyrillaceae or } \\
\text { Taxodium-Nyssa swamp; references as } \\
\text { above }\end{array}$ \\
\hline
\end{tabular}
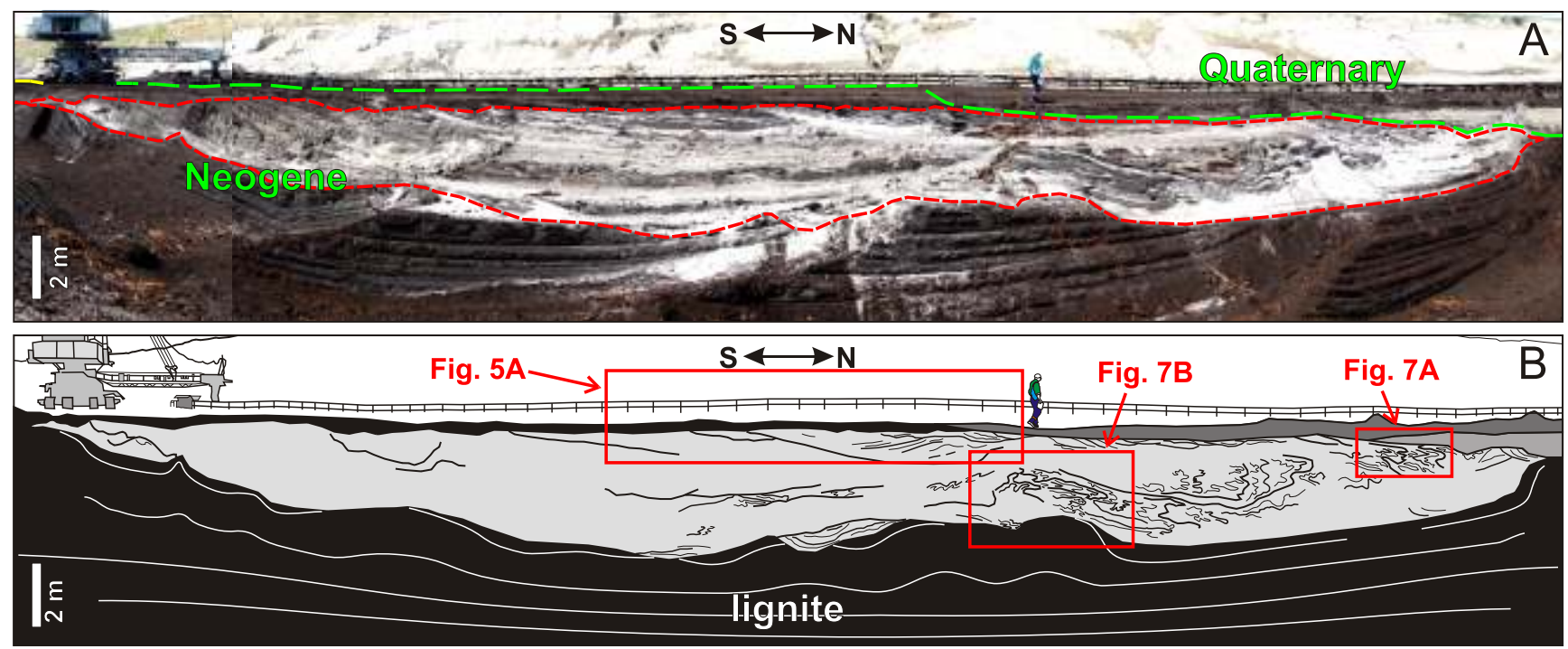

Fig. 4. General view and corresponding line drawings of the crevasse-splay succession within the first Mid-Polish lignite seam (MPLS-1) in the Tomisławice opencast mine, central Poland

Note the presence of the undeformed deposits in the lower- and uppermost parts of the siliciclastic succession; for location of the deposits studied see Figure 1B 
UPRIGHT FOLDS

Description. This type of fold is very rare within the crevasse-splay succession. However, several such structures have been identified in the uppermost part of the exposure, within generally undeformed deposits that are trough cross-stratified on a large scale (Fig. 5). In some places, the originally inclined beds are undulose rather than folded. One of the most visible examples is an upright fold in its initial stage of development (Figs. 5 and 6). It is $\sim 15 \mathrm{~cm}$ high, gentle (interlimb angle $>120^{\circ}$ ) and slightly asymmetrical to the north. The fold's core is made of sand, while its limbs are muddy. Furthermore, it is underlain by a continuous, undisturbed and $4-6 \mathrm{~cm}$ thick layer of mud; the sandy-muddy layers above this fold do not show any deformation (Fig. 6).

Interpretation. In the case of alternating layers of various lithology, even a slight slope of beds with different rheology may lead to downslope movement (Strachan and Alsop, 2006). For example, this is possible if more ductile and incompetent deposits (muds) form a continuous layer below, which can be called a "décollement" horizon or mud-rich detachment (Fig. 6; Ramsay and Huber, 1987; Dadlez and Jaroszewski, 1994; Strachan, 2008). Subsequently, the stratification of slumped sediments resting above the detachment may be folded due to horizontal shortening (buckling). Therefore, taking into account the geological background, these poorly-developed upright folds must be interpreted as having formed during initiation of the slumping process (Alsop and Marco, 2011).

\section{RECUMBENT FOLDS}

Description. These folds are best visible and developed in the northern part of the exposure (Fig. 4). The total thickness of a folded package is up to $2 \mathrm{~m}$, while individual folds are $0.2-0.6 \mathrm{~m}$ thick. These folds were observed over a distance of $\sim 20 \mathrm{~m}$, although they are best exposed in the southern and northernmost parts of the section (cf. Figs. 4 and 7 ). The folds examined are characterized by (sub)horizontal orientation of the axial planes, and hence, they may be termed recumbent folds (Rickard, 1971). However, as regards genesis, the most important feature is that they express general vergence towards both the south-southeast and north-northeast, that is, an average azimuth of $158^{\circ}$ and $16^{\circ}$, respectively (cf. Figs. 3 and 7).

Despite the general similarity in the lithology and geometry of these recumbent folds, there are also differences between them. All folds examined in detail are built of alternating layers of sand and mud, although in different proportions. For example, the majority of these folds are made up of sand and mud in almost equal quantity (Fig. 7A), while one of them, in the dominant portion, comprises beds of mud (Fig. 7B). The folds are tight (interlimb angle $<30^{\circ}$ ), albeit the more muddy ones are tighter and have almost parallel limbs and a smaller thickness. Furthermore, the basal boundaries of the recumbently-folded beds are always defined by mud-rich layers. By contrast, the top boundaries are truncated by younger slumps or eroded by overlying undeformed cross-strata (Fig. 7).
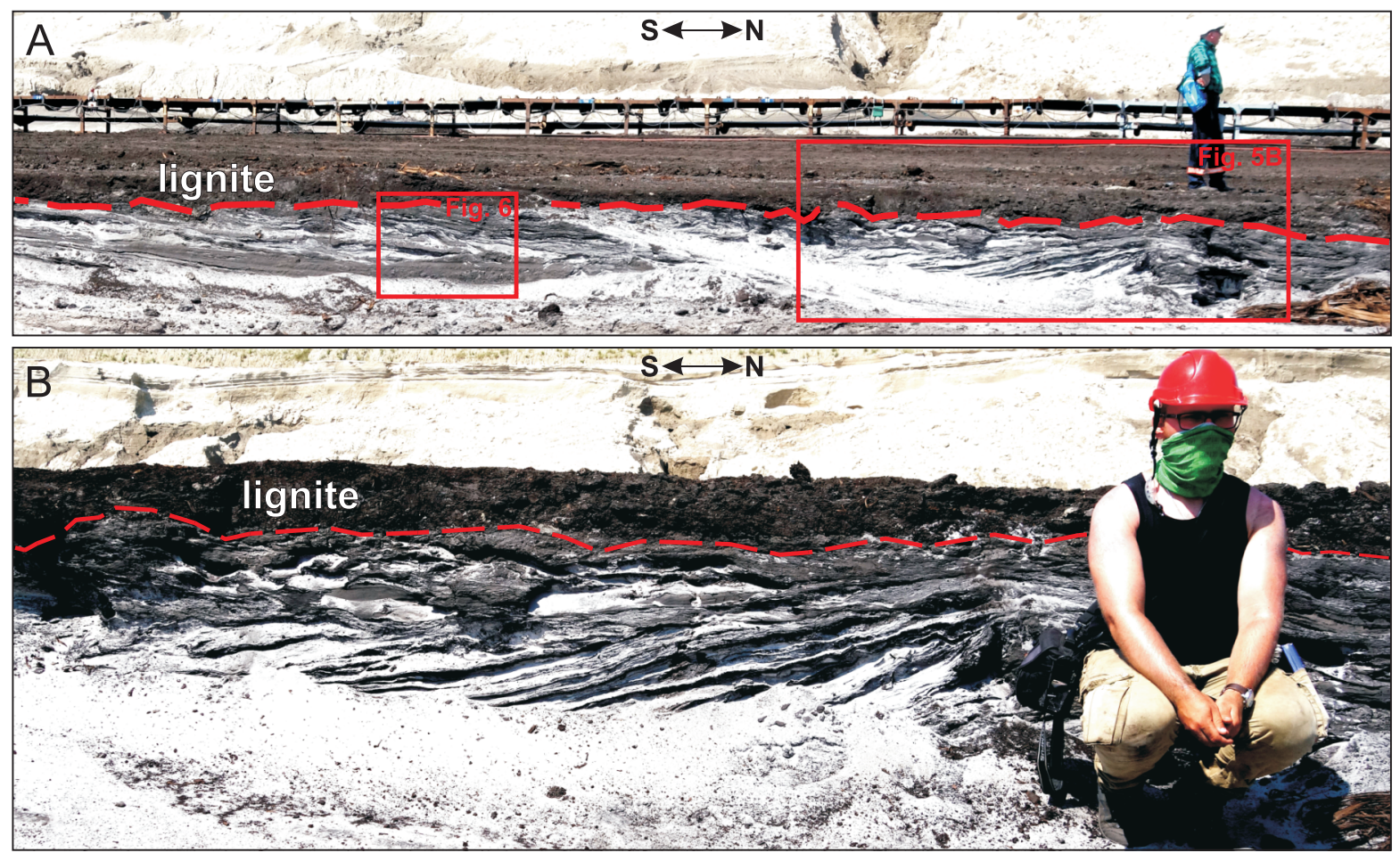

Fig. 5. Undisturbed deposits in the uppermost parts of the crevasse-splay body

A - general view; B - close-up view of sandy-muddy deposits with trough cross-stratification; note the alternating occurrence of sandy and sandy-muddy or muddy-sandy layers 


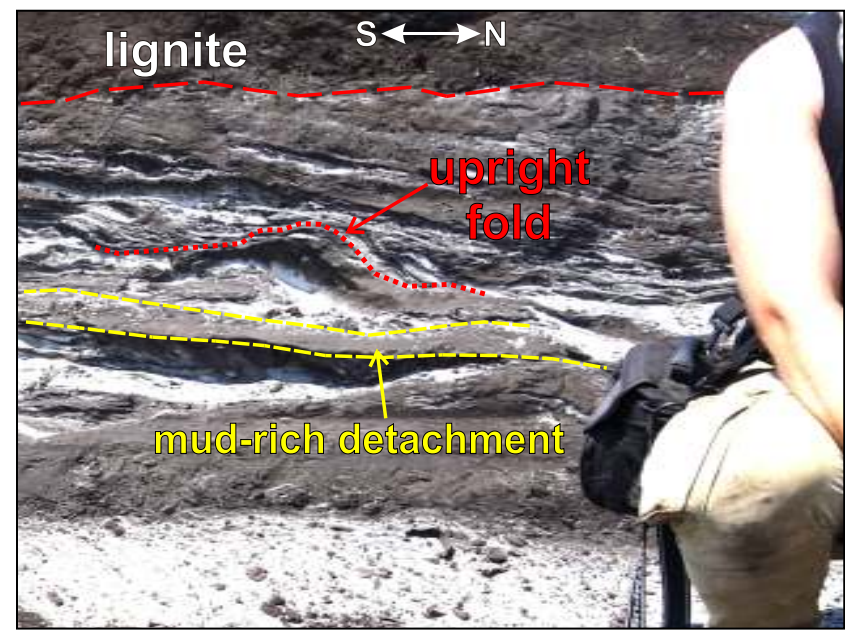

Fig. 6. Possible example of an upright fold at the initial stage of its development

Note the parallel arrangement of layers positioned under and above the weakly folded structure; for location see Figure 5A

Interpretation. The deformation structures described above represent type-A recumbent folds according to the terminology of Allen and Banks (1972) or type I as classified by Whitmore et al. (2015). In other words, they are slump folds that have well-defined stratification, form smooth parabolic curves, the axial planes are almost horizontal and their internal structure is not affected by irregular (i.e., disharmonic) secondary folding. Additionally, faulting and brecciation are absent, and the tops of this type of fold are truncated and eroded as in the cases interpreted (Fig. 7).

The origin of the recumbent folds from the Tomisławice lignite opencast mine is associated with slumping of the crevasse-splay sediments. As the vergences of these folds are in opposite directions (towards the south-southeast and northnortheast) and approximately perpendicular to the stratification, they are not the result of the inclination of the depositional surface towards the east (cf. Figs. 3 and 7). The slumping took place in accordance with the palaeoslope orientation, which is generally reflected in the fold vergence (e.g., Woodcock, 1979; Strachan and Alsop, 2006; Strachan, 2008).

Likely, peat/lignite compaction under the load of the overlying siliciclastic (i.e., crevasse-splay) sediments resulted in significant tilting of the alternating sandy-muddy beds. The average compaction ratio for the MPLS-1 is 2.0 (Widera et al., 2007; Widera, 2015); although for fresh peat layers, it may be several times greater (Rajchl et al., 2008; Van Asselen et al., 2009; Widera, 2019). Compactional subsidence was accompanied by extrusion of the water-saturated peat in a direction where the overlying siliciclastic sediments were thinner. This is indicated by the folded structure of the upper lignite beds, including their anticlinal elevation in the axial zone of the crevasse-splay lithosome. Hence, the slumps moved downslope, that is, to the south-southeast and north-northeast (cf. Figs. 4 and 7).

\section{DISCUSSION}

\section{ORIGINAL STRATIFICATION}

The folds investigated are characterized by well-preserved stratification of unconsolidated sandy-muddy facies (Figs. 5-7). However, the stratification is primary only in the lower and uppermost layers of the crevasse-splay succession (Figs. 4 and 5), while the remaining beds are deformed predominantly in the form of recumbent folds (Fig. 7). Considering these observations, it can be assumed that originally almost all siliciclastic facies were trough cross-stratified. Thus, well-preserved stratification may indicate that the liquefaction of sediments deformed penecontemporaneously (e.g., Owen, 1996; Byun et al., 2019) In the case of fluidisation, when the pore pressure is equal to or greater than the cohesive strength of the sediment, stratification can be destroyed (e.g., Molina et al., 1998; Alsop et al., 2016). Such recumbent folds can only arise in water-saturated deposits. Thus, liquefaction is necessary for the slumping and folding of unconsolidated sediments (McKee et al., 1962; Allen and Banks, 1972; Mazumder and Altermann, 2007; Whitmore et al., 2015; Shanmugam, 2017).

\section{MECHANISMS \\ OF SLUMPING AND FOLDING}

Due to the lack of evidence of tectonic activity at the time of formation of these intraformational deformation structures, tectonogenesis seems unlikely. Therefore, non-tectonic hypotheses directly related to the folding of fluvial deposits are discussed here. Two mechanisms for the generation of recumbent folds by flowing water are commonly noted, and this type of fold can be produced both experimentally (McKee et al., 1962), and on the basis of theoretical consideration (Røe and Hermansen, 2006). In the first case, strong shear is generated by sediment-laden currents, and in the second case, sudden changes in the flow regime can produce folds in the bedform (i.e., dune) foresets. However, neither of these mechanisms can be used to explain the origin of the Tomisławice recumbent folds. In these examples, the vergence of folds is unidirectional and consistent with stratification, while the recumbent folds examined face each other in a direction approximately perpendicular to the stratification (cf. Figs. 3, 4 and 7). Therefore, their origin must be connected with slumping caused by compaction of the underlying and relatively thick peat/lignite seam as explained in sub-section "RECUMBENT FOLDS".

\section{CONCEPTUAL MODEL}

Depositional and deformational processes, including of siliciclastic sediments within MPLS-1, are characterized by spatial and temporal variability in short-term cycles. This allowed us to examine in detail at least six stages of slump fold formation within the mid-Miocene crevasse-splay body from the Tomisławice opencast mine (Fig. 8). In the first stage, the natural levee was breached in the initial period of flooding. The river water 

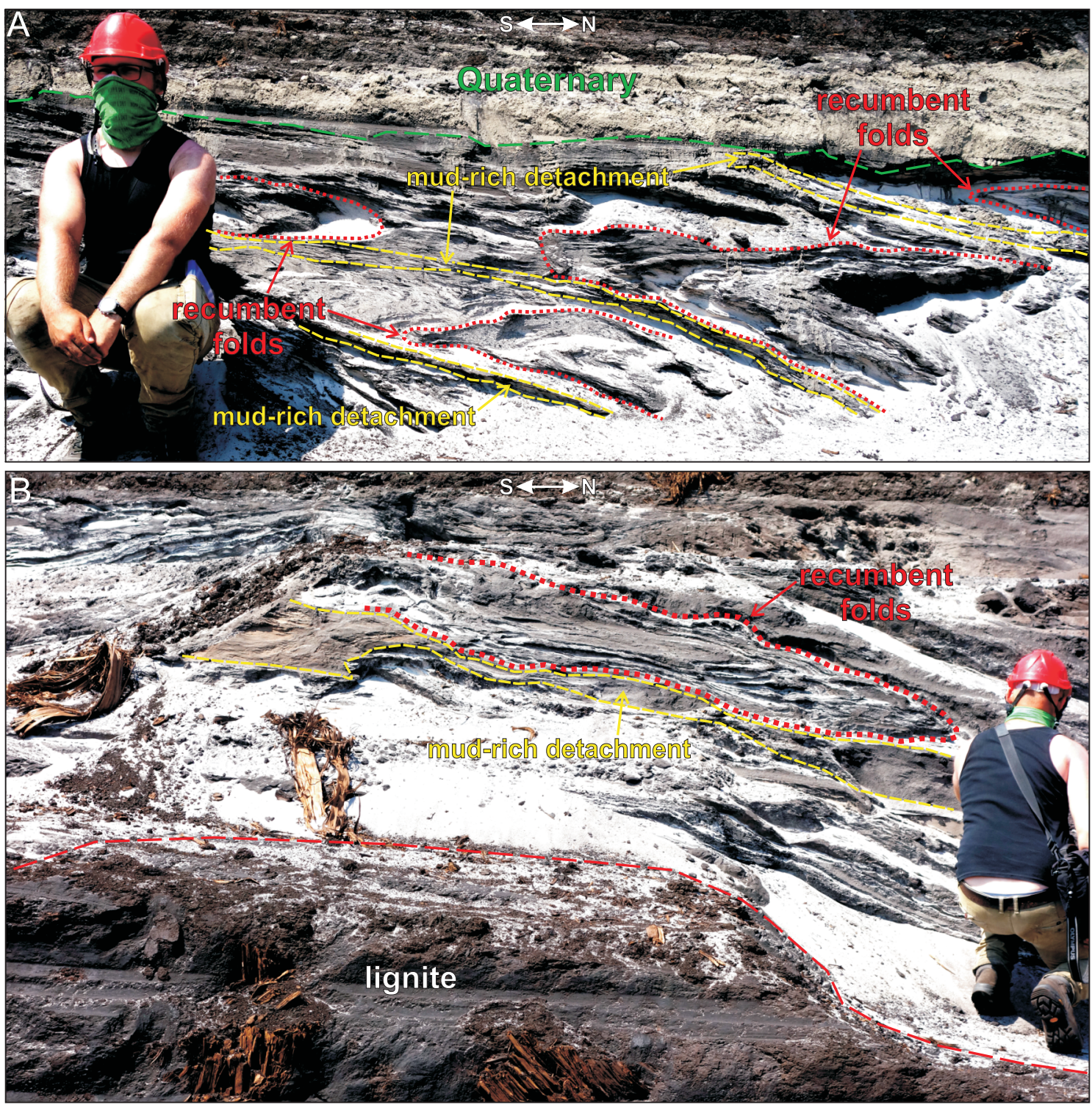

Fig. 7. Close-up view of the recumbent folds

A - fold vergence is approximately to the south;

B - vergence of most folds is approximately to the north; for location see Figure 4B

carried the siliciclastic load from the main channel and the levee, and spilled it onto the backswamp (mire) surface. The uppermost peat layers were then eroded, and siliciclastic sediments of the lowermost part of the crevasse splay were deposited (Fig. 8A). In places where the thickness of successively deposited siliciclastic sediments was greater, compaction affected the underlying peats. At this stage, the base of the siliciclastic layer and the peat roof were significantly undulose, including elevation along the axial part of the crevasse-splay succession. The water-saturated, alternately bedded sands and muds began to move on gradually steeping palaeoslopes. As a result, the upright folds arose, being the initial form of the slump process (Fig. 8B). The rapidly progressing peat compaction and the increase in the local slope of the freshly deposited siliciclastic sediments led first to the transformation of the upright folds into inclined folds (Fig. $8 \mathrm{C}$ ), and finally into recumbent ones (Fig. 8D). Relaxation of the compaction process in significantly compacted peats/lignites caused a lesser inclina- tion of the youngest siliciclastics. In other words, the slope inclinations of the sandy and muddy layers were too small to initiate slumping in converging directions (from south and north). Therefore, the uppermost siliciclastic beds are not deformed, and the primary trough cross-stratification is preserved (Fig. $8 \mathrm{E})$. In the final stage, peat vegetation covered the crevasse-splay lithosome. As a result, a peat bed was deposited and then transformed into the relatively thin upper bench of the MPLS-1 (cf. Figs. 3-5 and 8F).

\section{CONCLUSIONS}

Strongly slump-folded intraformational cross-beds are well developed in the Tomisławice lignite opencast mine in central Poland. Recumbent folds are characteristic of crevasse-splay deposits, but the three-dimensional example from the Tomisła- 


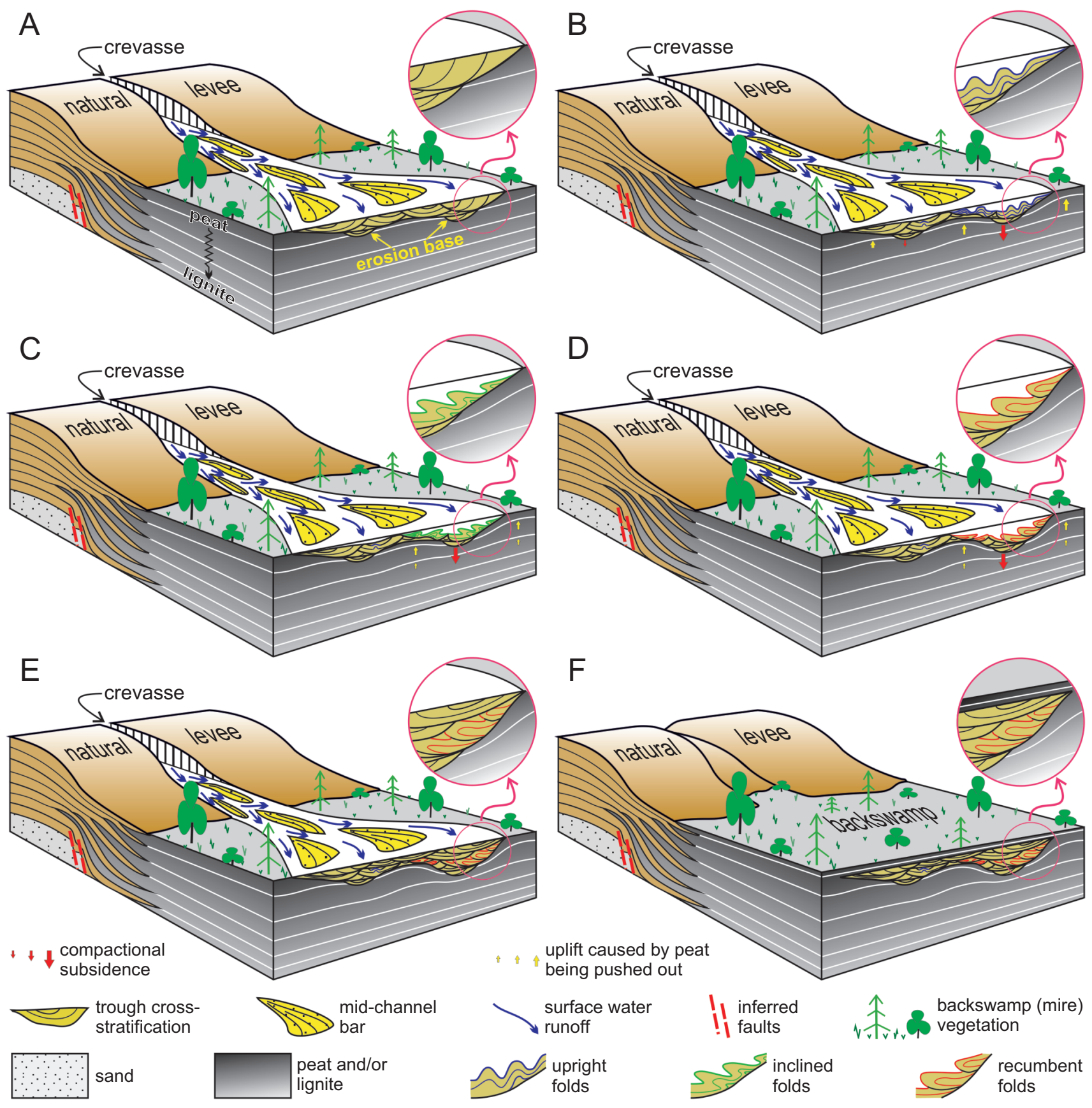

Fig.8.Ideal isedcon ceptualmodelf orthefor mationoft heslumpfo Idsw ithinthem id-Miocenecre vasse-splaysuc cession in the Tomisławice lignite opencast mine in central Poland

A - deposition of the alternating sandy-muddy layers with trough cross-stratification; B - Initial stage of upright fold formation; C - steepening of the original stratification caused by compaction of the underlying peat/lignite, stage of inclined fold generation; $\mathbf{D}$ - stage of the development of recumbent folds; $\mathbf{E}$ - deposition of younger crevasse-splay sediments and erosive truncation of the slump folds; $\mathbf{F}$ - covering of crevasse-splay deposits by a layer of younger peat, subsequently transformed into the upper bench of the lignite seam (MPLS-1)

wice lignite is spectacular and well-preserved. Therefore, this example formed a case study, and the results obtained lead to the following conclusions:

1. The siliciclastic deposits, representing the crevasse splay, are located within the currently mined lignite seam (MPLS-1) They are composed of alternating layers of sand and mud with different rheology that had various susceptibilities to deforma- tion. However, only plastic deformation was observed in the form of a few upright folds and more common recumbent ones.

2. These folds are located only in the middle part of the crevasse-splay succession. They are underlain and overlain by undisturbed trough cross-beds, while penecontemporaneously folded beds are characterized by deformed but well-preserved stratification. This means that during deformation the sediments were liquefied but not fluidised. 
3. The upright folds represent an initial slumping stage, while the recumbent ones are typical of the final stages of slump evolution. In the last case, they verge approximately towards the south and north, roughly perpendicular to the water-flow direction (on average eastwards) in the distributary channels of the crevasse splay.

4. Overall, the origin of these folds is linked with compaction of the thick underlying peat/lignite seam. The process of compactional subsidence was especially rapid in the initial stages of deposition of siliciclastic sediments on the backswamp surface. This resulted in the creation of south- and north-trending palaeoslopes, on which the slump folds developed.
Acknowledgements. The author would like to thank the management and staff of the Geological Department of the Konin Lignite Mine for enabling fieldwork on their property and for all logistical support. An anonymous reviewer and specifically G. Pieńkowski (Polish Geological Institute - National Research Institute) are acknowledged for their critical comments and suggestions, including linguistic corrections, which significantly improved the quality of the original manuscript. The current paper is financially supported by the National Science Centre (Poland), project no. 2017/27/B/ST10/00001.

\section{REFERENCES}

Allen, J.R.L., 1965. A review of the origin and characteristics of recent alluvial sediments. Sedimentology, 5: 89-191.

Allen, J.R.L., 1982. Sedimentary Structures: their Character and Physical Basis. Developments in Sedimentology, 30. Elsevier, Amsterdam.

Allen, J.R.L., 1984. Parallel lamination developed from upper-stage plane beds: a model based on the larger coherent structures of the turbulent boundary layer. Sedimentary Geology, 39: 227-242.

Allen, J.R.L., Banks, N.L., 1972. An interpretation and analysis of recumbent-folded deformed cross-bedding. Sedimentology, 19: 257-283.

Alsop, G.I., Marco, S., 2011. Soft-sediment deformation within seismogenic slumps of the Dead Sea Basin. Journal of Structural Geology, 33: 433-457.

Alsop, G.I., Marco, S., Weinberger, R., Levi, T., 2016. Sedimentary and structural controls on seismogenic slumping within mass transport deposits from the Dead Sea Basin. Sedimentary Geology, 344: 71-90.

Aslan, A., Autin, W.J., 1999. Evolution of the Holocene Mississippi River floodplain, Ferriday, Louisiana: insights on the origin of fine-grained floodplains. Journal of Sedimentary Research, 69: 800-815.

Bechtel, A., Widera, M., Woszczyk, M., 2019. Composition of lipids from the First Lusatian lignite seam of the Konin Basin (Poland) relationships with vegetation, climate and carbon cycling during the mid-Miocene Climatic Optimum. Organic Geochemistry, 138: 103908.

Bechtel, A., Widera, M., Lücke, A., Groß, D., Woszczyk, M., 2020. Petrological and geochemical characteristics of xylites from the First Lusatian lignite seam (Konin Basin, Poland): implications for floral sources, decomposition and environmental conditions. Organic Geochemistry, 147: 104052.

Bielowicz, B., 2012. A new technological classification of low-rank coal on the basis of Polish deposits. Fuel, 96: 497-510.

Bridge, J.S., 2003. Rivers and Floodplains: Forms, Processes, and Sedimentary Record. Blackwell Publishing, Malden.

Bristow, C.S., Skelly, R.L., Ethridge, F.G., 1999. Crevasse splays from the rapidly aggrading, sand-bed, braided Niobrara River, Nebraska: effect of base-level rise. Sedimentology, 46: 1029-1047.

Burns, C., Mountney, N.P., Hodgson, D.M., Colombera, L., 2017. Anatomy and dimensions of fluvial crevasse-splay deposits: examples from the Cretaceous Castlegate Sandstone and Neslen Formation, Utah, U.S.A. Sedimentary Geology, 351: 21-35.
Byun, U.H., van Loon, A.J., Kwon, Y.K., Ko, K., 2019. A new type of slumping-induced soft-sediment deformation structure: the envelope structure. Geologos, 25: 111-124.

Chomiak, L., 2020. Architecture, sedimentology and depositional model for the formation of crevasse splays within a lignite seam at the Tomisławice opencast mine near Konin in central Poland. Geologos, 26: 25-37.

Chomiak, L., Wachocki, R., Maciaszek, P., Widera, M., Zieliński, T., 2019a. Seismically-induced soft-sediment deformation in crevasse-splay microdelta deposits (Middle Miocene, central Poland). Geological Quarterly, 63 (1): 162-177.

Chomiak, L., Wachocki, R., Maciaszek, P., Widera M., Zieliński T., 2019b. Seismically-induced soft-sediment deformation in crevasse-splay microdelta deposits (Middle Miocene, central Poland) - reply. Geological Quarterly, 63 (2): 429-433.

Collinson, J.D., Thompson, D.B., 1982. Sedimentary Structures. Allen and Unwin, London.

Dadlez, R., Jaroszewski, W., 1994. Tektonika (in Polish) Wydawnictwo Naukowe PWN, Warszawa.

Dadlez, R., Marek, S., Pokorski, J., 2000. Mapa Geologiczna Polski bez kenozoiku w skali 1:1000 000 (in Polish). Państwowy Instytut Geologiczny, Warszawa.

Dasgupta, P., 2008. Experimental decipherment of the soft-sediment deformation observed in the upper part of the Talchir Formation (Lower Permian), Jharia Basin, India. Sedimentary Geology, 205: 100-110.

Davies-Vollum, K.S., Kraus, M.J., 2001. A relationship between alluvial backswamps and avulsion cycles: an example from the Willwood Formation of the Bighorn Basin, Wyoming. Sedimentary Geology, 140: 235-245.

Farrell, K.M., 2001. Geomorphology, facies architecture, and high-resolution, non-marine sequence stratigraphy in avulsion deposits, Cumberland Marshes, Saskatchewan. Sedimentary Geology, 139: 93-150.

Kasiński, J.R., Słodkowska, B., 2016. Factors controlling Cenozoic anthracogenesis in the Polish Lowlands. Geological Quarterly, 60 (4): 959-974.

Kędzior, A., 2016. Reconstruction of an early Pennsylvanian fluvial system based on geometry of sandstone bodies and coal seams: the Zabrze Beds of the Upper Silesia Coal Basin, Poland. Annales Societatis Geologorum Poloniae, 86: 437-472.

Kolcon, I., Sachsenhofer, R.F., 1999. Petrography, palynology and depositional environments of the early Miocene Oberdorf lignite seam (Styrian Basin, Austria). International Journal of Coal Geology, 41: 275-308. 
Kundu, A., Goswami, B., Eriksson, P.G., Chakraborty, A., 2011. Palaeoseismicity in relation to basin tectonics as revealed from soft-sediment deformation structures of the Lower Triassic Panchet formation, Raniganj basin (Damodar valley), eastern India. Journal of Earth System Science, 120: 167-181.

Kwiecińska, B., Wagner, M., 1997. Classification of qualitative features of brown coal from Polish deposits according to petrographical, chemical and technological criteria (in Polish with English summary). Wydawnictwo Centrum PPGSMiE Polskie Akademii Nauk, Kraków.

Kwiecińska, B., Wagner, M., 2001. Application of Reflectance in Natural and Technological Classification of Brown Coal (Lignite) (in Polish with English summary). Wydawnictwo Akademii Górniczo-Hutniczej, Kraków.

Leedal, G.P., Walker, G.P.L., 1950. A restudy of the Ingletonian Series of Yorkshire. Geological Magazine, 87: 57-66.

Li, W., Chen, J., Wang, L., Fang, X., Zhang, Y., 2019. Slump sheets as a record of regional tectonics and paleogeographic changes in South China. Sedimentary Geology, 392: 105525.

Lundegard, P.D., Samuels, N.D., 1980. Field classification of fine-grained sedimentary rocks. Journal of Sedimentary Petrology, 50: 781-786.

Maciaszek, P., Chomiak, L., Wachocki, R., Widera, M., 2019. The interpretive significance of ripple-derived sedimentary structures within the late Neogene fluvial succession, central Poland. Geologos, 25: 1-13.

Maciaszek, P., Chomiak, L., Urbański, P., Widera, M., 2020. New insights into the genesis of the "Poznań Clays" - upper Neogene of Poland. Civil and Environmental Engineering Reports, $\mathbf{3 0}$ 18-32.

Markič, M., Sachsenhofer, R.F., 1997. Petrographic composition and depositional environments of the Pliocene Velenje lignite seam (Slovenia). International Journal of Coal Geology, 33 229-254.

Mazumder, R., Altermann, W., 2007. Discussion on new aspects of deformed cross-strata in fluvial sandstones: examples from Neoproterozoic formations in northern Norway by S.L. Røe and M. Hermansen. Sedimentary Geology, 198: 351-353.

McKee, E.D., Reynolds, M.A., Baker, C.H., 1962. Experiments on intraformational recumbent folds in crossbedded sand. US Geological Survey Professional Paper, 450-D: 155-160.

Miall, A.D., 1977. A review of the braided-river depositional environment. Earth-Science Reviews, 13: 1-62.

Molina, J.M., Alfaro, P., Moretti, M., Soria, J.M., 1998. Soft-sediment deformation structures induced by cyclic stress of storm waves in tempestites (Miocene, Guadalquivir Basin, Spain). Terra Nova, 10: 145-150.

Moretti, M., Van Loon, A.J., 2014. Restrictions to the application of 'diagnostic' criteria for recognizing ancient seismites. Journal of Palaeogeography, 3: 162-173.

Moretti, M., Alfaro, P., Caselles, O., Canas, J.A., 1999. Modelling seismites with a digital shaking table. Tectonophysics, 304 369-383.

Moretti, M., Alfaro, P., Owen, G., 2016. The environmental significance of soft-sediment deformation structures: key signatures for sedimentary and tectonic processes. Sedimentary Geology, 344: $1-4$.

Olabode, S.O., 2016. Soft sediment deformation structures in the Maastrichtian Patti Formation, southern Bida Basin Nigeria: Implications for the assessment of endogenic triggers in the Maastrichtian sedimentary record. Open Journal of Geology, 6 : 410-438.

Owen, G., 1996. Experimental soft-sediment deformation: structures formed by the liquefaction of unconsolidated sands and some ancient examples. Sedimentology, 43: 279-293.

Piwocki, M., Ziembińska-Tworzydło, M., 1997. Neogene of the Polish Lowlands - lithostratigraphy and pollen-spore zones. Geological Quarterly, 41 (1): 21-40.
RajchI, M., Uličný, D., Mach, K., 2008. Interplay between tectonics and compaction in a rift-margin, lacustrine delta system: Miocene of the Eger Graben, Czech Republic. Sedimentology, 55: 1419-1447.

Ramsay, J.G., Huber, M.I., 1987. The Techniques of Modern Structural Geology - 2: Folds and Fractures. Academic Press, London.

Rickard, M.J., 1971. A classification diagram for fold orientation Geological Magazine, 108: 23-26.

Roberts, D.G., 1972. Slumping on the eastern margin of the Rockall Bank. North Atlantic Ocean. Marine Geology, 13: 225-237.

Røe, S.L., Hermansen, M., 2006. New aspects of deformed cross-strata in fluvial sandstones: examples from Neoproterozoic formations in Northern Norway. Sedimentary Geology, 186: 283-293.

Shanmugam, G., 2017. The fallacy of interpreting SSDS with different types of breccias as seismites amid the multifarious origins of earthquakes: Implications. Journal of Palaeogeography, 6 : 12-44.

Strachan, L.J., 2008. Flow transformations in slumps: a case study from the Waitemata Basin, New Zealand. Sedimentology, 55: 1311-1332.

Strachan, L.J., Alsop, G.I., 2006. Slump folds as estimators of palaeoslope: a case study from the Fisherstreet Slump of County Clare, Ireland. Basin Research, 18: 451-470.

Ta gın, C.K., Orhan, H., Türkmen, I., Aksoy, E., 2011. Soft-sediment deformation structures in the late Miocene elmo Formation around Adyıaman area, Southeastern Turkey. Sedimentary Geology, 235: 277-291.

Teichmüller, M., 1958. Rekonstruktion verschiedener Moortypen des Hauptflözes der niederrheinischen Braunkohle. Fortschrift in der Geologie von Rheinland und Westfalen, 2: 599-612.

Teichmüller, M., 1989. The genesis of coal from the viewpoint of coal petrology. International Journal of Coal Geology, 12: 1-87.

Ticleanu, N., Scradeanu, D., Popa, M., Milutinovici, S., Popa, R., Preda, I., Ticleanu, M., Savu, C., Diaconita, D., Barus, T., Petrescu, I., Dinulescu, C., Maftei, R., 1999. The relation between the lithotypes of Pliocene coals from Oltenia and their main quality characteristics. Bulletin of the Czech Geological Survey, 74: 169-174

Van Asselen, S., Stouthamer, E., Van Asch, Th.W.J., 2009. Effects of peat compaction on delta evolution: a review on processes, responses, measuring and modeling. Earth-Science Reviews, 92: 35-51.

Van Loon, A.J., 2009. Soft-sediment deformation structures in siliciclastic sediments: an overview. Geologos, 15: 3-55.

Van Loon, A.J., 2019. Seismically-induced soft-sediment deformation in crevasse-splay microdelta deposits (Middle Miocene, central Poland): comment. Geological Quarterly, 63 (2): 424-428.

Waldron, J.W.F., Gagnon, J.F., 2011. Recognizing soft sediment structures in deformed rocks of orogens. Journal of Structural Geology, 33: 271-279.

Whitmore, J.H., Forsythe, G., Garner, P.A., 2015. Intraformational Parabolic Recumbent Folds in the Coconino Sandstone (Permian) and Two Other Formations in Sedona, Arizona (USA). Answers Research Journal, 8: 21-40.

Widera, M., 2007. Lithostratigraphy and Palaeotectonics of the Sub-Pleistocene Cenozoic of Wielkopolska (in Polish with English summary). Adam Mickiewicz University Press, Poznań.

Widera, M., 2012. Macroscopic lithotype characterisation of the 1st Middle-Polish (1st Lusatian) Lignite Seam in the Miocene of central Poland. Geologos, 18: 1-11.

Widera, M., 2015. Compaction of lignite: a review of methods and results. Acta Geologica Polonica, 65: 367-368.

Widera, M., 2016a. Depositional environments of overbank sedimentation in the lignite-bearing Grey Clays Member: new evi- 
dence from Middle Miocene deposits of central Poland. Sedimentary Geology, 335: 150-165.

Widera, M., 2016b. An overview of lithotype associations forming the exploited lignite seams in Poland. Geologos, 22: 213-225.

Widera, M., 2017. Sedimentary breccia formed atop a Miocene crevasse-splay succession in central Poland. Sedimentary Geology, 360: 96-104.

Widera, M., 2019. What can be learned about the deposition and compaction of peat from the Miocene lignite seam exposed in the Chłapowo Cliff on the Polish coast of the Baltic Sea? Geology, Geophysics and Environment, 45: 111-119.

Widera, M., Kita, A., 2007. Paleogene marginal marine sedimentation in central-western Poland. Geological Quarterly, 51 (1): 79-90.

Widera, M., Jachna-Filipczuk, G., Kozula, R., Mazurek, S., 2007. From peat bog to lignite seam: a new method to calculate the consolidation coefficient of lignite seams, Wielkopolska region in central Poland. International Journal of Earth Sciences, 96: 947-955.

Widera, M., Chomiak, L., Gradecki, D., Wachocki, R., 2017a. Crevasse splay deposits from the Miocene of central Poland near Konin (in Polish with English summary). Przegląd Geologiczny, 65: 251-258.
Widera, M., Kowalska, E., Fortuna, M., 2017b. A Miocene anastomosing river system in the area of Konin Lignite Mine, central Poland. Annales Societatis Geologorum Poloniae, 87: 157-168.

Widera, M., Chomiak, L., Zieliński, T., 2019. Sedimentary facies, processes and paleochannel pattern of an anastomosing river system: an example from the Upper Neogene of Central Poland. Journal of Sedimentary Research, 89: 487-507.

Woodcock, N.H., 1979. The use of slump structures as palaeoslope orientation estimators. Sedimentology, 26: 83-99.

Wolf, M., 1988. Torf und Kohle. In: Sedimente und SedimentgesteineTeil II (ed. H. Füchtbauer): 683-730. Schweizerbart, Stuttgart.

Worobiec, E., Widera, M., Worobiec, G., Kurdziel, B., 2020. Middle Miocene palynoflora from the Adamów lignite deposit, central Poland. Palynology, 44: doi: 10.1080/01916122.2019.1697388

Zachos, J., Pagani, M., Sloan, L., Thomas, E., Billups, K., 2001. Trends, rhythms, and aberrations in global climate $65 \mathrm{Ma}$ to present. Science, 292: 686-693.

Zieliński, T., 2014. Sedymentologia. Osady rzek i jezior (in Polish). Adam Mickiewicz University Press.

Zieliński, T., Widera, M., 2020. Anastomosing-to-meandering transitional river in sedimentary record: a case study from the Neogene of central Poland. Sedimentary Geology, 404: 105677. 